\title{
A RAPID SLIDE-AGGLUTINATION METHOD FOR TYPING PNEUMOCOCCI BY MEANS OF SPECIFIC ANTIBODY ADSORBED TO PROTEIN A-CONTAINING STAPHYLO- COCCI
}

\author{
G. KRONVALL \\ Department of Medical Microbiology, University of Lund, Lund, Sweden
}

\section{Plate IV}

THE capsule-“ swelling” reaction (Neufeld, 1902; Neufeld and EtingerTulczynska, 1931; Lund, 1963 and 1970; Burke et al., 1971) is more widely used than the gel-precipitation and bacterial-agglutination techniques (Kirkman, Fischer and Pagano, 1970) for typing pneumococci by means of their capsular polysaccharides. It is, however, somewhat laborious as a routine test. A slide-agglutination method is here described that renders pneumococcal typing quick and easy to perform. Specific anti-pneumococcal antibodies, when added to a stabilised suspension of staphylococci, become bound to the protein A on the cell wall via the Fc structures of the $\gamma$-globulin (Forsgren and Sjöquist, 1966; Kronvall and Williams, 1969; Kronvall and Frommel, 1970), thus orientating the Fab-located antibody-combining sites outwards (Lind, Reyn and Birch-Andersen, 1972). When pneumococci of the corresponding capsular type are added, co-agglutination occurs with the antibody-coated staphylococci. Preliminary experiments indicate that the method may also have wider applications in serological work.

\section{MATERIALS AND METHODS}

Bacterial strains. Staphylococcus aureus, strain Cowan I, (NCTC no. 8530) capable of producing large amounts of protein A, was used throughout the investigations for the preparation of the typing reagent. The strain was grown in CCY-broth (Arvidson, Holme and Wadström, 1971) or on the same medium solidified with 1.5 per cent. agar. Strains of pneumococci were obtained from routine cultures in our diagnostic laboratory; all 89 of the strains used showed $\alpha$-haemolysis and sensitivity to optochin. The capsular types were determined with the aid of diagnostic pneumococcal antisera by means of the capsule"swelling" reaction (Lund, 1963; Lund and Munksgaard, 1967). The pneumococcal strains were kept on blood-agar plates in anaerobic jars at $37^{\circ} \mathrm{C}$. Only fresh subcultures were used in the tests performed.

Diagnostic pneumococcal antisera. Type-specific rabbit anti-pneumococcal sera were purchased from the Pneumococcus Department, Statens Seruminstitut, Copenhagen, Denmark, The antisera used included polyvalent "omni "-serum, pooled antisera A, B, C, D, E, F, G, H, I, as well as specific sera against individual types (Lund, 1963; Lund and Munksgaard).

Isotope-labelled $\gamma$-globulin. Human immunoglobulin G (AB Kabi, Sweden; batch no. 44791) was labelled with 125 I by the method of McConahey and Dixon (1966); $\gamma$-globulin uptake was calculated as described by Kronvall, Quie and Williams (1970). 
Preparation of stabilised staphylococci. S. aureus, strain Cowan I, was grown in CCYbroth overnight with aeration (Arvidson et al.) and the harvested bacteria were washed twice with phosphate-buffered saline (PBS; $0.15 \mathrm{M} \mathrm{NaCl}, 0.01 \mathrm{M}$ phosphate, $p \mathrm{H} \mathrm{7.4)}$ ). The bacteria were then suspended in 0.5 per cent. formaldehyde in PBS and kept at room temperature for $3 \mathrm{hr}$ (Lind and Mansa, 1968). The formaldehyde-treated suspension was then washed four times in PBS and finally adjusted to a concentration of 10 per cent. (v/v). Bacteria treated in this way are stable for weeks as far as the protein-A content is concerned (Kronvall et al., 1971), in contrast to untreated bacteria (Kronvall et al., 1970). It was found that heating the bacteria after formaldehyde treatment made them more suitable for use in the method described. This treatment consisted of heating the bacteria by pumping the suspension at a rate of $500 \mathrm{ml}$ per hour through a $180-\mathrm{cm}(6 \mathrm{ft})$ length of tubing (internal diameter $4 \mathrm{~mm}$ ) which was submerged in an $80^{\circ} \mathrm{C}$ waterbath. This treatment killed the bacteria and also prevented the development of a rather foul odour probably caused by enzymatic degradation of the formaldehyde-treated cells. The combined treatment of the staphylococci with formaldehyde and heat yielded a particle that was stable for months when stored at $4^{\circ} \mathrm{C}$ and capable of being coated with large amounts of $\gamma$-globulin.

\section{RESULTS}

\section{$\gamma$-Globulin absorbing capacity of stabilised staphylococci}

The capacity of staphylococci to absorb $\gamma$-globulin was measured by the use of 125I-labelled normal human $\gamma$-globulin (Kronvall et al., 1970). Corrections for presence of non-reactive $\gamma$ G-3 were included in the calculations. Formaldehyde-treated bacteria showed a maximal uptake of about $2 \mathrm{mg}$ of $\gamma$-globulin for every $\mathrm{ml}$ of a 10 per cent. suspension. Heating did not alter the number of protein-A sites available.

\section{Preparation of typing reagent}

To $1.0 \mathrm{ml}$ of a 10 per cent. (v/v) suspension of formaldehyde- and heattreated staphylococci, $0 \cdot 1 \mathrm{ml}$ of pneumococcal typing serum was added. After mixing, the staphylococci were washed and resuspended in PBS, containing $0 \cdot 1$ per cent. sodium azide to a final concentration of 1 per cent., and were then stored at $4^{\circ} \mathrm{C}$. Reagents prepared in this way showed no loss in reactivity or specificity after storage for more than $5 \mathrm{mth}$.

\section{Typing of pneumococci with antibody-coated staphylococci}

Staphylococci coated with specific antibody in this manner were used in the typing of 89 strains of pneumococci. One or more colonies of the strain to be tested were emulsified in two drops of typing reagent on a microscopic slide. The mixture was observed for $c .2 \mathrm{~min}$., and the presence or absence of agglutination was recorded. In most instances a positive reaction occurred within seconds. The polyvalent " omni "-reagent, however, required at least a minute before the agglutination was fully developed. All pneumococcal strains tested could be easily and quickly typed by the slide-agglutination method and the results obtained were in complete agreement with results of typing by means of the capsular " swelling" reaction. Of the 89 strains of pneumococci tested, 23 were type 19,22 were type 6,19 were type 23,3 were type 7,3 were type 9 , 4 were type 11,6 were type 18,2 were type 15,2 were type 22,2 were type 31 
KronVALL

SPECIFIC ANTIBODY ADSORBED to PROTEIN A

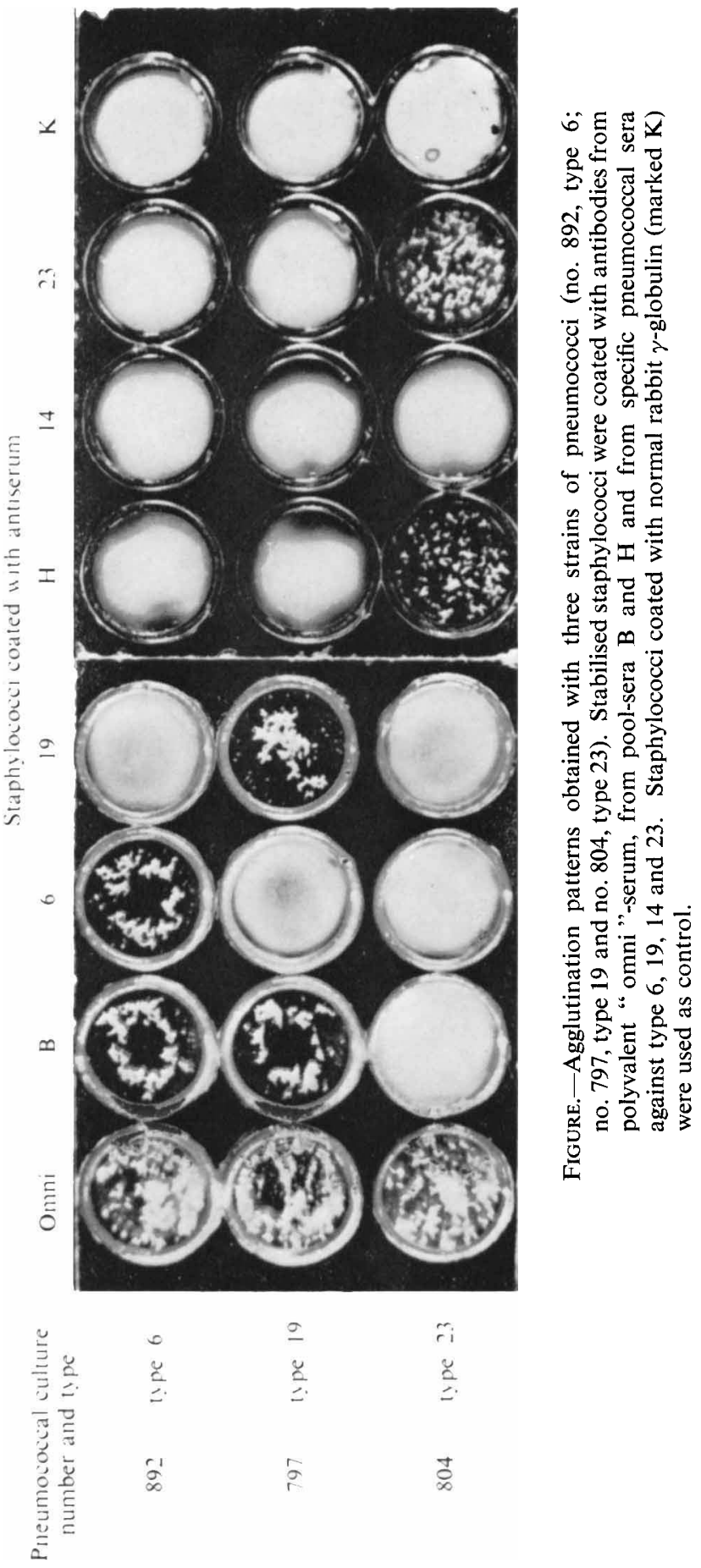


and 1 each were type 4, 35 and 37. Typical agglutination reactions are shown in the figure. The major advantage of the method lies in its rapidity, but the amount of antiserum needed is also much less than for the capsule "swelling" reaction.

With 17 of the 89 cultures, the agglutination test showed weak reactions for one or more capsular type in addition to the very strong reaction given with the typing reagent that corresponded to the "capsular-swelling" type of the strain. Parallel capsule-" swelling" tests failed to detect the presence of other capsular antigens in these strains. These weak cross-reactions persisted after the strains had been subcultured. A probable reason for these discrepancies is the higher sensitivity of the agglutination method, revealing either contaminating antibodies in the typing sera or true cross-reacting antigens in the pneumococci. Work is in progress to evaluate these possibilities.

Stabilised staphylococci such as the ones used in the present experiments might obviously be coated with specific $\gamma$-globulin antibodies directed against any other type of antigen. Specific antisera against Haemophilus influenzae, type $b$, bovine serum albumin, human chorionic gonadotrophin, and adenovirus types 7 and 12 (in collaboration with Dr Jaro Ankerst), were used for making reagents. These reagents were tested with the corresponding antigens as well as a range of other antigens. In all cases, regardless of whether the antigen was bacterial, viral or a soluble protein, agglutination of staphylococci occurred only with the particular antigen against which the original antiserum was directed.

\section{DISCUSSION}

The method of pneumococcal typing I have described makes use of carrier particles coated with specific antibodies. These particles are staphylococci that form protein $\mathbf{A}$ and had been treated with formaldehyde (Lind and Mansa, 1968) and heated to stabilise this antigen on the cell surface. This treatment appears to inactivate the enzymes that cause autolysis. Antibodies of the IgG class become bound to these particles via their Fc fragment, which reacts with protein A, and thus they become orientated with their Fab structures directed outwards. Co-agglutination occurs when the particles are mixed with a suspension of pneumococci of homologous type. The main advantage of this new agglutination method is the ease of the tests and the rapidity of the results.

\section{SUMMARY}

A new slide-agglutination method was developed for the serological typing of pneumococci. Type-specific antibodies were bound to stabilised, protein-A containing staphylococci through their Fc fragments. The combining sites of the antibodies remained available to the corresponding type-specific antigen; when pneumococci were mixed with a suspension of the stabilised staphylococci coated with homologous antibody, strong agglutination occurred rapidly. Eighty-nine pneumococcal strains were typed by this agglutination method. The results obtained were in complete agreement with those of typing by Neufeld's capsule-" swelling" method. 
I am grateful to Miss Kerstin Lundborg for excellent technical assistance and to Mrs Eva Svadling for secretarial help.

\section{REFERENCES}

ARVIDSON, S., Holme, T., AND WADSTRÖM, T. 1971. Influence of cultivation conditions on the production of extracellular proteins by Staphylococcus aureus. Acta path. microbiol. scand. $B, 79,399$.

Burke, J. P., Klein, J. O., Gezon, H. M., and Finland, M. 1971. Pneumococcal bacteremia. Review of 111 cases, 1957-1969, with special reference to cases with undetermined focus. Am. J. Dis. Child., 121, 353.

Forsgren, A., AND SJöQuIST, J. 1966. "Protein A " from S. aureus. I. Pseudo-immune reaction with human $\gamma$-globulin. J. Immun., 97, 822.

Kirkman, J. B., JR, Fischer, Janet, AND Pagano, J. S. 1970. A microtiter plate technique for the agglutination typing of Diplococcus pneumoniae. J. Infect. Dis., 121, 217.

Kronvall, G., AND Frommel, D. 1970 . Definition of staphylococcal protein A reactivity for human immunoglobulin $\mathrm{G}$ fragments. Immunochem., 7, 124.

Kronvall, G., AND Williams, R. C., JR 1969. Differences in anti-protein A activity among IgG subgroups. J. Immun., 103, 828.

Kronvall, G., QUIE, P. G., AND Williams, R. C., JR 1970. Quantitation of staphylococcal protein A: determination of equilibrium constant and number of protein $\mathrm{A}$ residues on bacteria. J. Immun., 104, 273.

Kronvall, G., Dossett, J. H., Quie, P. G., and Williams, R. C., JR 1971. Occurrence of protein $\mathbf{A}$ in staphylococcal strains: quantitative aspects and correlation to antigenic and bacteriophage types. Infect. Immun., 3, 10.

LIND, INGA, AND MANSA, B. 1968. Further investigation of specific and non-specific adsorption of serum globulins to Staphylococcus aureus. Acta path. microbiol. scand., 73, 637.

LiND, INGA, ReYN, Alice, AND BIRCH-ANDERSEN, A. 1972. Electron microscopy of staphylococcal protein $\mathrm{A}$ reactivity and specific antigen-antibody reactions. Acta. path. microbiol. scand. B, 80, 281.

Lund, ERNA 1963. Polyvalent, diagnostic pneumococcus sera. Acta path. microbiol. scand., 59, 533.

LUND, ERNA 1970. Types of pneumococci found in blood, spinal fluid and pleural exudate during a period of 15 years (1954-1969). Acta path. microbiol. scand. B, 78, 333.

Lund, ERna, AND MunksgaARd, A. 1967. A new pneumococcus type. Type 12A. Acta path. microbiol. scand., 70, 305.

McConahey, Patricia J., AND Dixon, F. J. 1966. A method of trace iodination of proteins for immunologic studies. Int. Archs Allergy Appl. Immun., 29, 185.

Neufeld, F. 1902. Ueber die Agglutination der Pneumokokken and über die Theorieen der Agglutination. Z. Hyg. InfektKrankh., 40, 54.

Neufeld, F., AND Etinger-TulCZYNSKa, R. 1931. Nasale Pneumokokken-infektionen und Pneumokokkenkeimträger im Tierversuch. Z. Hyg. InfektKrankh., 112, 492. 